Dossiê: Fundamentalismos e Democracia - Artigo Original (c) (1)

\title{
Efeitos patológicos do fundamentalismo: o religar como resposta à convivência saudável
}

\author{
Pathological effect of fundamentalism: \\ Reconnecting as a response to a healthy coexistence
}

Jovino Pizzi *

\begin{abstract}
Resumo
A proliferação de seitas tornou o Brasil e a América Latina em espaços para uma renovação dos fundamentos religiosos. Embora a laicidade da democracia moderna, grande parte da sociedade conserva um acentuado simbolismo religioso. Com o avanço do neopentecostalismo, os discursos de partidos e grupos populistas conseguem sensibilizar setores importantes da sociedade. Esses movimentos fundamentalistas reaproximam a religião da política e da economia. Não poucas vezes, esse fundamentalismo estrafalário assume um caráter beligerante. De um lado, o texto realiza uma crítica especulativo-filosófica em torno aos efeitos patológicos desse discurso e, por outro, pretende ressaltar a proposta de uma con-vivência saudável. Não se trata de conceituar, mas de salientar como os efeitos de um fundamentalismo estrafalário gera anomias sociais. Por isso, além do diagnóstico, o estudo aponta como alternativa uma filosofia da vida. Ela é uma exigência incondicional para superar as anomias sociais. Nesse sentido, a noção de democracia representativa oferece os contornos saudáveis para re-ligar a convivência em um mundo pluralista.
\end{abstract}

Palavras-chave: Fundamentalismo. Patologias sociais. Mercado da fé. Convivência.

\begin{abstract}
The proliferation of sects has made in Brazil and Latin America a space for a renewal of religious foundations. Despite the secularity of modern democracy, much of society retains a marked religious symbolism. With the advancement of neo-Pentecostalism, the speeches of populist parties and groups managed to raise awareness in important sectors of society. These fundamentalist movements bring religion closes to politics and economics. Not infrequently, this staggering fundamentalism takes on a belligerent character. On de one hand, the text conducts a speculative-philosophical analysis around the pathological effects of this discourse and, on the other it tries to highlight the proposal for a healthy coexistence. It is not a question of conceptualizing, but of highlighting how the effects of a step-by-step fundamentalism generate social anomalies. Therefore, in addition to the diagnosis, the study points out the alternative of a philosophy of life. In this sense, the notion of representative democracy offers healthy skyline to reconnect coexistence in a pluralistic world.
\end{abstract}

Keywords: Fundamentalism. Social pathologies. Faith market. Coexistence.

Artigo submetido em 30 de junho de 2020 e aprovado em 25 de fevereiro de 2021.

* Doutor em Ética y Democracia pela Universitat Jaume I, Espanha. Professor da UFPel. País de origem: Brasil. E-mail: jovino.piz@gmail.com 


\section{Introdução $^{1}$}

O século XX apresentou um teor secular expressivo, envolvendo questões políticas, culturais, científicas e religiosas. Nas democracias liberais, a sociedade admite um alto grau de laicização do Estado, embora os cidadãos amanhem um nível de religiosidade considerável. Diante disso, o embate a respeito das fronteiras entre os campos político, econômico e religioso continua na pauta das discussões atuais.

A controvérsia ganha novos contornos com o afloramento de um fundamentalismo político-religioso imanentista do tipo estrafalário. ${ }^{2}$ Em um contexto brasileiro e latino-americano, o avanço das seitas evangélicas, com viés neopentecostal, alberga um tipo de perversão da normalidade tradicional. A proliferação de "igrejas", com denominações sui generis e com uma nominata bastante diversificada, transformou a fé em um símbolo comercialista.

Embora seja uma suposição controversa, existem modificações importantes nos cânones do discurso religioso. O aspecto central concerne no apego ao fundamentalismo, cujos efeitos direcionam a interpretação bíblica a uma literalidade ortodoxa, ao tempo que reúne também valores e tradições particulares e, através desse modo, opor-se às mudanças e inovações sociais, culturais, científicas etc. No contexto de uma nova ortodoxia fundamentalista, o neopentecostalismo alimenta uma perspectiva devocional e uma disciplina moral rigidamente neoconservadora. Com suas características estrafalárias, isto é, com traços nada habituais, extravagantes e exóticos, a preocupação concerne a seus efeitos adversos não apenas na vida pessoal das pessoas, mas também nas definições das pautas políticas e na agenda nacional de alguns países.

\footnotetext{
${ }^{1}$ Texto vinculado ao Projeto Institucional da Universidade Federal de Pelotas, Ministério de Educação do Brasil, com o número 38420422053/CAPES-PRINT782483P.

2 Do dialeto italiano strafalario, o adjetivo é traduzido ao idioma português como estrafalário, denotando a forma extravagante de pensar e de agir. Seu uso é comumente no idioma espanhol, mas, no português, é um tanto infrequente.
} 
Por isso, o foco nas patologias sociais remete aos elementos geradores de anomias sociais, consequência das mudanças no teor e na interpretação condicente ao discurso neopentecostal. No caso, o âmbito religioso aparece como um fenômeno que interfere na vida individual das pessoas e, na sua versão fundamentalista, se interpõe no processo democrático, com interfaces que congregam política, religião e economia. Em outras palavras, o mote do novo evangelismo não significa apenas uma presença significativa na mídia, mas, e principalmente, aos efeitos na ingerência política. A nova onda avaliza um projeto ultraconservador.

Com o fim de elucidar o tema, o estudo se divide em cinco partes. A primeira delas salienta o vácuo preenchido por um exemplo religioso estrafalário, ou seja, de um idealismo sem transcendência e, portanto, diabólico (1). O segundo discorre sobre um tipo de perversão "mórbida" que torna as pessoas enamoradas pela morte (2). O terceiro ponto expõe a religião desde uma perspectiva dianética (3). O quarto item remete ao verticalismo das dinastias estrafalárias, uma ingerência na democracia com bases no modelo centrado na figura do "soberano" (4). O quinto ponto salienta trata de salientar a necessidade de re-enamoramento, ou seja, na reversão de uma perversão mórbida para conceder lugar à perspectiva de uma convivência que nasce do re-ligar (5).

\section{0 idealismo de uma religiosidade monolíngue}

Hoje em dia, a noção de pós-secularidade consolidou-se como uma categoria de análise. Um dos pontos centrais concerne ao papel das religiões no mundo atual (MICHELINI, 2018). Na sua versão mais habitual, a secularização supõe uma “cultura aberta, livre de dogmas e de doutrinarismos rígidos” (YTURBE, 2016, p. 299). Mesmo assim, as dúvidas a respeito da secularização da cultura europeia seguem vivas, assim como da "tradução secular" dos potenciais religiosos (HABERMAS, 2015). Nesse sentido, é possível afirmar que a Europa se articula desde uma cultura político-democrática secular, enquanto a América Latina persiste na esteira de tradições religiosas vigorosas. 
A discussão tem como base dois autores ligados à Escola de Frankfurt. Erich Fromm é um dos representantes da primeira geração, conquanto Habermas é posterior. A ideia não é realizar um estudo comparativo entre os dois, mas na tentativa de salientar, desde duas percepções e contextos distintos, a nova onda neopentecostal e fundamentalista que, especialmente no Brasil, assume um tom exacerbador na ingerência política do país. A versão mais ortodoxa das igrejas evangélicas nega os direitos humanos e/ou sociais e, ainda, se opõe ao diálogo intercultural voltado à con-vivência saudável entre as "gentes", isto é, a hospitalidade entre povos, culturas, etnias e nações.

Fromm, no livro La patología de la normalidad (1994), diz que a sociedade moderna preencheu o vazio de sentido através de "novas" formas de religião. Habermas, inspirado em Claude Lefort, afirma que a secularização moderna evidenciou "um centro desguarnecido" (HABERMAS, 2015, p. 219). Para Lefort, a Revolução Francesa apregoou o desaparecimento do âmbito religioso e de seus efeitos sobre a política. Todavia, alijado das instituições, o discurso religioso manteve-se em standby, o que significa que, de fato, ele "permaneceu vivo na esfera privada" (LEFORT, 1998, p. 215).

Então, se os ideais do modelo feudal não foram adequadamente preenchidos pela modernidade, esse espaço foi paulatinamente ocupado por outras "crenças" com áurea religiosa. A desvalorização das formas religioso-metafísicas deu lugar a inovações, abrindo caminho para a corporificação de inúmeras propostas, muitas delas com acentuado teor fundamentalista. Atualmente, em muitos países, multiplica-se o leque plurifacetário de crenças e instituições de cunho religiosofundamentalista. Às vezes, seu caráter integra elementos nada convencionais à normalidade das tradições.

No seu livro, Fromm se atém à "dianética", que realiza uma espécie de simbiose entre religião e ciência. No caso, não se trata de traços psicológicos ou psicossomáticos, mas na reinterpretação da proposta de Lafayette Ronald Hubbard. A origem da palavra dianética remete ao "aventureiro" escritor norte- 
americano (também conhecido por Ron Hubbard), fundador de uma "igreja” com bases na cienciologia (Scientology).

Nos anos 50 do século passado, Hubbard utilizou a expressão dianética com a promessa de alivio dos males psicossomáticos. Seus escritos eram de ciência ficção, fantasia e prometeísmo científico-supersticioso. Sua proposta anunciava a libertação da mente de imagens nocivas e, através do ritualismo dianético, pressagiava livrar os indivíduos das anomias provocadoras pelas disfunções ligadas à imaginação e à fantasia individual das pessoas.

Para Fromm, esse é apenas um exemplo de doutrinas, supostamente religiosas, configuradas como igrejas "às vezes sem divindade” e, por isso, desprovidas de qualquer centro convergente. Seus discursos propalam a liberação das mentes das representações nocivas e sem sentido, utilizando, para isso, a insinuação de prosperidade e de bem estar. Com estilo pitoresco - e, de certo modo, ridículo - tais discursos induzem as pessoas com promessas de superação de problemas, realçando um salvacionismo de tipo imanente, ou seja, de uma dádiva individualizada e verticalista.

No fundo, a modernidade substituiu os dogmas religiosos pelos do mercado. No campo simbólico, a fé se transformou em artigo com valor de troca. Com isso, o ritualismo religioso abandonou o foco do sagrado para, então, assumir a dimensionalidade imanente da prosperidade e do bem estar individual. O imaginário desse mercado da fé se entrecruza com o sistema financeiro e a acumulação de bens materiais. O fator mercadológico representa, pois, o eixo de convecção e motivo para auferir um resultado material não só em termos de autorrealização pessoal, mas - e principalmente - também no aspecto da rentabilidade financeira e econômica.

No plano da graça, os méritos estão reproduzidos nos extratos contábeis e financeiros (individuais ou de empresas e instituições), demonstrativos da verdadeira agraciação - ou, então, da desgraça - de quem atende, ou não, a preceitos hiperindividualistas. Essa comprovação reflete a amostragem particular 
relativa aos "talentos" e às habilidades individuais, criando desejos e uma "fome de consumo" sem precedentes. Essa seria a nova mística ligada ao comércio da fé. Como afirma Amor Pan, esse mercado simbólico consagra o "deletério reino do individualismo sem regras" (2018, p. 275).

Como é possível perceber, a lacuna da espiritualidade religiosa tradicional foi preenchida por uma obsessão mercadológica, sem qualquer relação direta com os aspectos transcendentes, sejam eles artísticos, culturais, religiosos etc. Assim, prospera o imediatismo de uma paixão empreendedorista e imanentista, deixando de lado e desconsiderando "tudo o que não for rentável" (CORTINA, 2017, p. 42). Evidentemente, o elemento ritualístico segue vivo no imaginário social, pois, conforme Fromm, o drama humano se enfrenta a um vazio que não foi completamente destituído. No fundo, o ritualismo convencional não desapareceu por completo.

Em relação ao catolicismo, por exemplo, persistem elementos chaves de sua enunciação dramática. Eles estão ligados “à ressurreição, ao nascimento, da morte, de Deus, da Virgem ou de outros elementos; perdura também a beleza das vestimentas e dos templos" (FROMM, 1994, p. 39-40). Nessa dramaticidade humana, há um cerimonialismo que permite, ao sujeito, entrar em sintonia "com aspectos fundamentais de si mesmo." Nesse sentido, persevera uma espécie de reminiscência ligados a elementos constitutivos da tradição cristã, evidenciados nos ritos e celebrações religiosas.

No entanto, as mudanças dos últimos tempos fez com que esse ritualismo, e sua dramaticidade, se transformassem em uma espécie de crença sem divindade. No fundo, o "novo" código litúrgico gira ao redor dos símbolos tangíveis e à promessa de prosperidade material. Essa idolatria se converte "em centro de atenção, em objeto de adoração, não apenas de gente estúpida, mas também de alguns importantes intelectuais de nosso tempo" (FROMM, 1994, p. 38). De uma forma ou de outra, a dimensão religiosa, no sentido lato de um conjunto de orientações, está presente em todas as pessoas. No entanto, o crucial refere-se à 
escolha, que não ocorre entre "uma religião boa e uma religião má, ou entre uma religião melhor ou pior" (FROMM, 1994, p. 34).

Na concepção de Fromm, a escolha fundamental, que cerceia qualquer ser humano, está na disposição ou no desejo de "amar e cooperar”, em oposição aos impulsos "de destruir, dominar, reprimir, sufocar a vida." Nessa ambivalência, as escolhas pessoais e sociais refletem o fato de "sermos bons ou perigosos para o mundo" (FROMM, 1994, p. 34). Essa preferência apenas pode ser identificada a partir do ponto de vista racional. Não se trata de uma escolha aleatória. As preferências seguem o caminho do enamoramento pela vida ou, então - na direção oposta -, a opção persegue a senda perniciosa e, no caso, instigaria o arruinamento da convivência.

Fromm não destoa do fato de as religiões se articularem através de ritualismos e idealizações. No entanto, as escolhas podem impulsar o "amor" e a cooperação ou, no sentido contrário, apregoam a beligerância. Por sua vez, Habermas entende que as religiões se circunscrevem no horizonte das tradições, crenças e convicções de comunidades particulares. Elas apresentam um potencial semântico concernente a uma herança que não pode, simplesmente, ser desprezada. Todavia, a imposição das doutrinas religiosas frente ao pluralismo e às exigências de uma sociedade democrática - para usar a expressão de Habermas -, realça o dogmatismo irracional de ideais religiosos. Por isso, o que causa ou é motivo de indignação advém da maneira como determinados ideais religiosos são propalados como exigências para todos.

Evidentemente, os indivíduos podem escolher, entre diversas opções, os símbolos e práticas com maior sentido. Todavia, a religião é "pertinente e legítima para os indivíduos; no entanto, ela não pode ser imposta a toda a sociedade” (YTURBE, 2016, P. 300). Na concepção de Fromm, a imposição transforma tais ideais em "os piores do mundo [...], pois, entre outros motivos, eles conseguem impressionar as pessoas precisamente por seu idealismo, o que parece dignificar suas peripécias mais diabólicas" (FROMM, 1994, p. 34). 
Como já foi salientado, Fromm ressalta o vazio religioso da modernidade ocidental, o qual foi sendo preenchido por um tipo de culto sem divindade. Por um lado, o cientificismo moderno atrofiou a razão, transformando as certezas em dogmas. Quanto o assunto se relaciona à fé, não se trata de classificar entre religiões boas ou más, mas na separação entre ideais, sejam eles religiosos ou não. A capacidade racional permite, então, a triagem entre os procedimentos capazes de gerar benevolência e colaboração entre as pessoas e, por conseguinte, encontrar disposição para renunciar ao preceituário ligado à destruição e à morte.

O problema se agrava - e, então, é motivo de preocupação - quando o vácuo da modernidade passa a ser preenchido por uma espécie de morbidez tresloucada, isto é, por uma ortodoxia fundamentalista sem conexão com os ideais de um conviver saudável. Na sua versão ultraconservadora, essa tendência se ampara em um fundamentalismo monolíngue, ou seja, a um tipo de "monólogos paroquiais disfarçados" ou acobertados por uma "falsa" perspectiva universalista (PIZZI, 2017). No caso, o fundamentalismo - seja ele religioso, ideológico, político ou de outras conotações - abriga uma compreensão unilateral, opondo-se à alteridade de mundos, de pontos de vista e de estilos de vida.

Considerando seu caráter monolíngue, os conteúdos semânticos das religiões neopentecostais são deveras perigosos, porque acarreta na coação sistemática a respeito de um ideal que não pode ser universalizado. Nesse sentido, a imposição de qualquer conteúdo religioso não passa de um idealismo anômico, porque sua gramática se apresenta desalinhada com a perspectiva de uma sociedade pluralista. Assim, o fundamentalismo passa a ser uma perversão mórbida, a ponto de desbaratar as bases de um Estado democrático de direitos. Seus efeitos anômalos podem, portanto, sacrificar e vitimar os ideais de uma convivência saudável, aspectos a serem examinados na continuação. 


\section{A perversão "dianética" e o enamoramento pela morte}

Como foi destacado, Fromm entende que as escolhas humanas se defrontam a dois rumos distintos. Em relação a essa ambivalência, Adela Cortina afirma que os seres humanos "não somos apenas egoístas, inteligentes ou estúpidos, pois somos também, entre outras qualidades, seres pré-dispostos a cuidar de nós mesmos e dos demais" (2013, p. 49-50). A utilização da segunda pessoa do plural remete ao "nós" de um humanismo do qual "todos" pertencemos. Essa autoreferencialidade tem relação com a pré-disposição a ser cultivada, pois não se trata de algo natural. Por isso, ela se relaciona à educação cívica, pois a autorrealização individual está diretamente vinculada a sua socialização, ou seja, à interação e a con-vivência com os demais.

O problema está na triagem, ou seja, nas condições de possibilidade para deliberar e decidir-se entre um caminho ou outro. Para Fromm, a dianética é um magistral convite à perversidade, pois se trata de um fenômeno "verdadeiramente estrafalário" (1994, p. 37). Com origem no idioma inglês, dianetics foi traduzido também por dianoética. Etimologicamente, o termo se vincula ao rol de virtudes aristotélicas do âmbito intelectual do ser humano. Separadas das virtudes éticas, elas não fazem parte das virtudes do agir, mas às funções cognitivas ou racionais do ser humano. Como se trata de um processo de aprendizagem, essas virtudes permitem realizar os cálculos necessários para determinar o justo meio que auxilia no exercício das virtudes morais.

Nada disso é mencionado por Fromm. Ele se atém ao aspecto estrafalário da dianética de Hubbard, uma vez que suas publicações se transformaram em "centro de atenção, em objeto de adoração [...].” Esse fenômeno desconcertante realça "a necessidade de acreditar em alguma coisa, ainda que impregnada de absurdos e que denegue o sentido comum dos fatos; e mais: ainda que ela seja uma crença que corporifique alguma esperança irracional a respeito de algo" (FROMM, 1994, p. 38). Através de seu modo excêntrico, Hubbard consegue potencializar uma perversão necrófila. 
De acordo com Fromm, movimentos com tais características são frequentes nos Estados Unidos. Ele inclusive faz alusão à mania da psicanálise, "tão irracional como a dianética", pois ela alimenta um "fanatismo" destituído de qualquer racionalidade. Embora a insensatez e a incapacidade de julgar, esses movimentos se transformam em espécie de confraria religiosa. Nessa direção, Fromm menciona outro exemplo de cerimonial: as corridas de touros. Para ele, trata-se de "um rito com características bem específicas, pois expressa a luta entre a brutalidade e o espírito, a inteligência e a graça. São dois princípios que se contrariam, simbolizados pelo touro e pelo toureiro" (FROMM, 1994, p. 40).

O intrigante é o objetivo final, isto é, a derrota e a morte do outro; no caso, o touro. Essa experiência aproxima o sujeito à crueldade da devastação, a estampa iconográfica da impiedade de matar. Sem dúvidas, prospera o desejo de que o toureiro vença. E isso, de acordo com Fromm, revela um espírito oculto e camuflado em relação à aspiração por matar; em outras palavras, ao "enamoramento da morte" (FROMM, 1994, p. 117). Trata-se, pois, de uma inclinação necrófila, uma perversão mórbida de algumas - ou muitas - pessoas que, mesmo "estando vivas", alimentam o desejo perverso em relação à vida.

Essa crueldade também ocorre na vida cotidiana. O filósofo espanhol Juan Carlos Aparisi relata um acontecimento entre alunos de um colégio. Em determinado momento, "algumas crianças começam a golpear ou a exasperar outro colega. Enquanto isso, um colega deles grava o fato com seu aparelho telefônico, rindo e zombando da criança que está sendo agredida" (2018, p. 408). Por certo, não se trata de uma simples brincadeira ou de uma diversão qualquer. A questão é a desforra de um jogo maléfico (ou demoníaco) de discriminação, ou seja, de uma crueldade com um teor belicista, não condizente com as exigências mínimas de uma convivência social saudável.

No horizonte político, Fromm se reporta ao nazismo e ao estalinismo. O primeiro passo desses regimes foi substituir as "antigas" religiões por outras "como marco de referência e objeto de adesão". Sem dúvidas, "os nazis e os estalinistas 
compreenderam bem isso, introduzindo novos ritos" (FROMM, 1994, p. 41). Suas doutrinas exigem uma adesão cega, uma disposição tresloucada com o fim de entregar a vida - que, para Fromm, é deveras perniciosa -, porque tal outorga representa também o "abandono da razão, o que é muito pior” (FROMM, 1994, p. 37). No caso dos regimes ditatoriais latino-americanos, a renúncia de uma racionalidade serviu de mote para denegrir as reivindicações democráticas e, assim, poderem perseguir seus críticos e agentes de distintas organizações da sociedade civil.

A questão chave está na personificação de uma "liderança" capaz de atrair milhares de pessoas, seja através de afagamentos ou, então, por meio da disseminação de um medo aterrorizante. No caso do fundamentalismo religioso especialmente em relação às denominadas igrejas evangélicas de caráter neopentecostal -, há sempre pessoas alimentando o espírito belicista, confrontando os adeptos com os ímpios. Em outras palavras, a bipolarização aufere aos concorrentes, opositores, discordantes e aos adversários como aqueles que representam a encarnação dos "endemoniados" e, por este motivo, devem ser afastados da convivência de forma peremptória. Em parte e de forma diferente das religiões monoteístas, a atual retórica do neopentecostalismo parece explicitar uma espécie de luta livre, permanente e sem tréguas, com a pretensão de alijar o "suposto" inimigo.

Esse delírio estrafalário entre gladiadores se revela também nos filmes de guerra, lutas armadas, desenhos animados, noticiários e exposição sistemática da violência e, inclusive, em "competições" esportivas. A divulgação contumaz desse fenômeno parece satisfazer a ânsia de um espírito estrafalário. A finalidade não é propriamente o aspecto deleitante e a gratuidade mútua, mas o gozo e a satisfação pela desforra e a aniquilação. Na verdade, há apenas um "problema real": o combate beligerante entre pessoas dispostas a infligir e eliminar o competidor. No caso, alguém deve, necessariamente, ser o vencedor, pois se trata de uma guerra fraticida (entre nações, povos, etnias, ideologias, partidos políticos, classes, gênero ou sexos, nas competições esportivas etc.). 
Outro exemplo, mencionado por Fromm, refere-se ao assassinato de uma mulher, em uma zona agrícola. O relevante do fato não é o crime em si, mas a visitação continuada ao local, durante semanas seguidas, por muita gente. Em uma cultura carente de sentido, parece intensificar-se a fascinação em torno à necessidade de "entrar em contato com qualquer fenômeno dramático" (FROMM, 1994, p. 41). A mesma fascinação está vinculada aos romances policialescos e relatos de guerra - e, como foi destacado acima - na ostensiva e sistemática exibição cinematográfica e pelo noticiarismo da violência; enfim, um propagandear profundamente ligado a um belicismo maligno e fora do comum. Essa cultura se alimenta de um fundamentalismo perdulário, nutrindo uma morbidez que perverte a noção de vida, do bem viver e do con-viver.

\section{A morbidez fundamentalista na esteira perdulária de tipo dianético}

Fromm investiga o papel da religião com base na dianética. Para ele, o elemento crucial evidencia aspectos patológicos de um fundamentalismo estrafalário. De modo esquisito e pouco convencional, extravagante, ridículo e, portanto, deselegante e sem qualquer ímpeto de vivacidade, estrafalário é antônimo de normal, habitual, usual e adequado.

Por isso, a ortodoxia - seja de caráter dianético ou de qualquer dogmatismo - pode inspirar um fundamentalismo religioso em tempos de colapso mundial. Por um lado, trata-se de interpretar o sentido de um pensar e agir exóticos, isto é, infrequente e um tanto banal ou tresloucado. Nessa propositura, destaca-se a capacidade de alguns poucos conseguirem tamanha admiração e afeiçoamento. Por outro lado, esse tipo de fundamentalismo evoca e desperta um desprezo pela democracia e sua divisão de poderes, bem como das representações da sociedade civil, do debate público e saudável a respeito das reivindicações por direitos de qualquer natureza. Às vezes, essa inclinação tétrica serve de leitmotiv de um messianismo catastrófico, tendência típica dos tempos de bipolaridades extremadas. 
A partir dessas, é possível identificar uma espécie de ritualismo, como se fosse religião, mas que, no fundo, se apega a um modelo de Estado autoritário e verticalista. Em outras palavras, essa ortodoxia evangélica, que congrega religião, política e economia, se apresenta com um manto adornado e atraente, mas que, no seu interior, alimenta o ódio, a violência e a discriminação. Trata-se, pois, de intensificar os discursos de ódio (hate speech) "cuja finalidade consiste em propagar, incitar, promover ou justificar o ódio em relação a determinados grupos sociais" e, então, abrir caminho para que eles "possam ser tratados com hostilidade" (CORTINA, 2017, p. 32).

Às vezes, esses discursos atraem signatários e milicianos e, através de um fanatismo mórbido, desqualificam qualquer postulado alheio. Nesse sentido, a fobia e a hostilidade decorrem não apenas em relação à raça ou etnia, mas também às crenças e práticas religiosas, orientação ou identidade sexual, ideologia, etc. Ou seja, eles não subestimam apenas as ciências ou determinadas áreas do conhecimento, pois desdenham até mesmo as outras religiões, propondo uma relação ameaçadora e beligerante. Nesse sentido, existe uma aproximação com o secularismo tradicional, o qual "considerava que os dogmas e as asserções de fé são incompatíveis com o conhecimento científico e filosófico” (MICHELINI, 2018, p. 165).

Como foi salientado, a dianética realça o indivíduo como tal. Ou seja, esse modelo destaca a liderança de um sujeito convergente, auxiliado por acólitos e signatários. Eles são excêntricos, com indumentárias das mais diversas espécies, com o fim de atrair a atenção do maior número de pessoas. Sua maneira de conquistar é, muitas vezes, pitoresca, com elementos de comicidade e/ou patéticos. O conjunto da obra utiliza também tons de voz estridentes, alternando sessões de silêncio com outras de gritaria e/ou vozerios simultâneos. Enfim, com o objetivo de atrair e seduzir, tudo vale, como se fosse uma espécie de luta livre, com seus asseclas contorcendo-se à espera de alucinações e condenações. 
Além dos enfeites nos altares, os mestres das cerimônias também utilizam ornamentos em seus corpos. No caso de manifestações públicas, há bandeiras, cores, símbolos e marcas que os identificam. Essa centralidade se relaciona a um elemento imanente e, portanto, reforça a ausência de uma divindade transcendente. Ao concentrar a divindade nos cerimonialistas, desloca-se o eixo de modo a realocá-lo na figura excêntrica, teatral e monolíngue dos mestres de cerimônias (isto é, o "pastor" ou lideranças). Desse modo, os discursos dos líderes reforçam o desdém pelos ímpios para, então, centralizar o ritual na figura extravagante da teatralidade dramatúrgica do líder da confraria.

Fromm menciona o contexto norte-americano, local de proliferação de religiões e seitas de diferentes matizes. No entanto, o fenômeno se acentua no contexto brasileiro e latino-americano, com articulações sem precedentes. $\mathrm{Na}$ verdade, a atual revitalização neopentecostal passa pela criação de "igrejas" de inumeráveis denominações, credos com tendências diversificadas. No Brasil, a expansão dessas congregações assumiu uma amplitude exuberante. Não poucas vezes, esse discurso estrafalário de tipo cristofascista ${ }^{3}$ por exemplo, faz parte da verbosidade impositiva. Sua excentricidade ímpar interfere, inclusive, na definição dos princípios de um Estado democrático de direitos. No caso, a noção de uma esfera pública pluralista passa a ser aplastada por um discurso monolíngue. Para Habermas, a pretensão de substituir a legitimidade do tipo secularizada pelos cânones religiosos - tradicionais ou fundamentalistas - não passa de um "obscurantismo" (2015, p. 216).

A suspeita ganhou contornos ainda mais lúgubres frente ao célere crescimento "dos pentecostalistas ou do muçulmanismo radical", com uma perspectiva eminentemente fundamentalista (HABERMAS, 2015, p. 265). Eles rechaçam "o mundo moderno", afastando-se dos padrões "normalizados" da sociedade atual. A semântica da predicação concilia "espiritualismo com a esperança de aproximação do apocalipse, com rígidas concepções morais e uma

\footnotetext{
${ }^{3}$ Cf. https://cartacapital.com.br/opinião/edir-malafaia-e-valdomiro-os-cristofascistas-que-menosprezan-o-coronavirus, acesso em 02 de abril de 2020.
} 
crença literal da Bíblia” (HABERMAS, 2015, p. 266).

Para Habermas, a grande maioria desses movimentos religiosos, surgidos nos anos 60 e 70 do século passado, apresenta um sincretismo californiano. Eles compartem com os grupos evangélicos, mas de "uma maneira não institucionalizada, da prática religiosa" (HABERMAS, 2015, p. 266). Esse movimento aparece também, por exemplo, no Japão, onde, nas últimas décadas, surgiram em torno de "quatrocentas seitas desse tipo, que fusionam elementos do budismo e da religião popular com teorias pseudocientíficas e exotéricas" (HABERMAS, 2015, p. 266). Habermas também menciona o caso da seita chinesa Falun Gong que, embora as represálias do governo, conta com aproximadamente 80 milhões de adeptos. No caso de regimes islâmicos, o "terrorismo" é apenas um exemplo a ilustrar o potencial político-religioso de poder.

No Brasil, no meu modo de ver, esse tipo de discurso pode conformar-se em uma eventual aspiração para promover uma possível res-pública militar neopentecostal Terra brasilis. De forma bastante sucinta, trata-se de um projeto de poder ultraconservador, com acentuada ingerência na política, com vistas a recriar uma nova identidade nacional. Tal tendência aparece com um impulso muito forte no período final das eleições brasileiras de 2018 e, de modo especial, na atual gestão governamental. Nesse sentido, há evangélicos neopentecostais que se transformaram em "parceiros" do governo, na tentativa de criar, por exemplo, uma nova cultura dos direitos humanos. Além de negar os direitos dos mais pobres, eles alimentam os meios para a neutralizar os avanços e/ou conquistas sociais.

No conjunto da obra, além dos aspectos de uma teologia da prosperidade e do comércio da fé, está intrínseca a ideia de uma tentativa que procura vincular a razão pública com os "movimentos fundamentalistas", uma espécie de "terrorismo guarnecido de religião" (HABERMAS, 2015, p. 267). Nesse sentido, torna-se evidente outro aspecto no momento de compreender o fundamentalismo neopentecostal e de sua influência na vida social, política, cultural e religiosa de nossos dias. Não se trata apenas de efeitos midiáticos, mas de uma reaproximação 
- extremamente perigosa - em vistas a reinterpretar a pauta da vida política e social a partir dos cânones de um neoconservadorismo fundamentalista.

$\mathrm{Na}$ verdade, existem dois traços básicos, através dos quais o atual reencantamento a respeito do fenômeno religioso define sua iconografia dos elementos de uma ortodoxia ultraconsevadora. Por um lado, a centralidade personificada de seus representantes e, por outro, o triunfalismo estrafalário.

No jogo da simulação, as lideranças conseguem captar a atenção e envolver as pessoas. Não se trata propriamente de um carisma ou do caráter vocacional, mas de uma maneira repetitiva e persuasiva de seduzir as pessoas, tento como base os cânones de um catálogo de ritualizações instituído previamente. Ao redor do líder, há sempre um grupo mais próximo de menestréis e acólitos, sempre atentos ao desenrolar da cerimônia, conforme a sequencialidade dos cânones. Esse grupo insiste em testemunhar e confirmar o agraciamento.

O conjunto de símbolos, apresentam-se, como imanentes, utensílios ou objetos de uso pessoal ou conservados como relíquias dignas de veneração. No caso, há sempre uma quantia monetária a ser paga pelos acólitos. Embora o voluntarismo das contribuições, essas doações certificam a adesão às lideranças que enriquecem cada vez mais. A excelência empreendedora enuncia o espírito triunfador de quem se encontra "bem situado no mundo acadêmico, político, artístico ou dos negócios" (CORTINA, 2017, p. 21). Em outras palavras, os triunfadores fazem parte da casta privilegiada - que viaja, se veste bem e faz pregações e se apresenta em diversos lugares. Esse grupo de indivíduos "bem sucedidos" se compõe de desportistas, banqueiros, inversores financeiros e, principalmente, pastores ou signatários de igrejas.

Por isso, a perspectiva de uma remissão imediata requer sempre uma contribuição generosa por parte dos fiéis. E aí está o sentido de uma teologia da prosperidade, cujo produto a ser negociado faz parte do imaginário espiritualista. Ou seja, o mercado se refere a bens simbólicos relacionados à fé como tal, mas no horizonte de uma realização puramente imanente, isto é, à rentabilidade material. 
Por isso, o discurso neopentecostal promete uma rentabilidade que vincula a graça ao acúmulo de bens - de seus líderes, é evidente.

Nesse sentido, a perspectiva salvacionista considera o abençoamento como algo meramente particular, pois a graça é recompensa individual. O verticalismo monológico ou - na expressão de Habermas (2015, p. 218) - a "perspectiva monolíngue dos cidadãos religiosos" supõe a salvação como algo eminentemente particular. Essa atitude não é sensível à crítica social e, por esta razão, deixa de nutrir qualquer simpatia por políticas voltadas a diminuir as desigualdades e a pobreza. Há, pois, uma rejeição peremptória às políticas voltadas a uma sociedade equitativa. Por isso, a "validez canónica" dos conteúdos imobiliza qualquer “objeção crítica” (HABERMAS, 2015, p. 66). Em decorrência, consolida-se uma desmedida centralização do âmbito religioso na figura de uma "liderança", acompanhado por uma equipe de menestréis ou "operários". Daí, então, a pergunta: como justificar esse esquema verticalista?

\section{0 verticalismo de dinastias estrafalárias}

Para justificar o verticalismo monolíngue, as contribuições de Habermas remetem ao modelo dinástico desse fundamentalismo religioso, centralizado na figura do soberano. Na obra Mundo de la vida, política y religión (2015), Habermas se reporta a era axial, com o fim de retomar o modelo de representação amparado na "lei sagrada". Ele lembra o período em que a figura do rei apresentava uma aura sagrada, incorporando, ao mesmo tempo, a iconografia humana e divina. Nessa configuração, "a sociedade como um todo dependia da figura do soberano" (HABERMAS, 2015, p. 208). Esse modelo aparece entre 4.000 e 3.000 A. C., no Egito, Mesopotâmia, Israel e na China, articulando "imagens metafísicas e religiosas de mundo" (HABERMAS, 2015, p. 209). Tal configuração permitiu às "elites intelectuais, formadas por profetas e sábios, monges e predicadores ambulantes, transcender o acaecer mundo-vital, incluído o político" com o fim de resguardá-lo na sua totalidade (HABERMAS, 2015, p. 209). 
Nessa articulação, há dois movimentos significativos. Por um lado,

o poder político gerenciava a política religiosa para se assegurar da aprovação das instituições e dos grupos religiosos; por outra parte, as convicções religiosas, a causa de sua referência individual de salvação, mantiveram um momento de indisponibilidade: a crença na legitimidade não podia ser manipulada sem comedimentos. É possível rastrear este frágil equilibro até a entrada da Idade Média europeia, nas relações entre o imperador e o papa. (HABERMAS, 2015, p. 209).

Como é possível perceber, o texto salienta um esquema de poder e controle que exercia a gerência das questões religiosas e políticas em todas as suas dimensões. A "política religiosa" se traduz em institucionalização administrativa, com uma hierarquia, um sistema jurídico e um corpo administrativo. Desse modo, configura-se um sistema de controle sobre os fiéis, de modo que tudo permanecesse subordinado ao poder central e hegemônico. Além do mais, é nítida a tensão concernente ao controle político da sociedade. Por isso, com o fim de garantir o modelo, as instituições religiosas deviam amancebar-se com o ordenamento político e jurídico da sociedade. Com isso, a aliança entre os poderes - religioso e civil - poderia garantir os cânones de uma política institucional que centralizava, na figura do monarca, os poderes hegemônicos das duas coroas.

Dessa forma, o monarca absorvia dois subsistemas, o religioso e o civil, na forma de "lei sagrada" com o fim de garantir a força legitimadora do poder (HABERMAS, 2015, p. 208). Para o autor, o influxo dos argumentos, sejam "convincentes ou escandalosos", exercem uma influência determinante "sobre a formação pública de opinião e vontade" (2015, p. 208). Na verdade, a convecção na figura do soberano - uma personificação homogeneizadora e monolíngue - define a forma de pensar e de agir, em conformidade com segundo os cânones estabelecidos de forma dinástica. A figura do monarca refletia um personalismo individualista - e de suas hilariancias -, às vezes sem vínculos com os dogmas propriamente religiosos. 
Evidentemente, “a secularização do Estado não é sinônimo de secularização da sociedade" (HABERMAS, 2015, p. 216). Embora haja uma relativa aceitação do aspecto secular do Estado, a sociedade continua preservando determinados rituais de cunho religioso. Atualmente, o reencanto em torno aos fundamentos religiosos “obriga a repensar as causas desse retorno da religião ao espaço público [...] e do seu lugar no contexto do processo histórico" (YTURBE, 2016, p. 302). Nesse ínterim, é importante retomar a questão do vazio de uma cultura perpassada de anomias.

Para Fromm, a sociedade moderna criou uma espécie de totalitarismo que combina e reúne, numa só figura, o "culto ao herói, culto ao trabalho, do medo e do terror” (1994, p. 83). Essa intimidação também é ressaltada por Claude Lefort, cuja paradoxalidade pode ser identificada na morte de Danton e de seus companheiros. Para evocar a unidade do movimento revolucionário, todos os "opositores devem ser eliminados”. Nesse caso, o terror não é objeto de simples retaliação, mas um exercício permanente de ameaça, exclusão e exterminação (LEFORT, 1988, p. 60).

A institucionalização do exercício do terror agrega ortodoxias de um discurso semântico de tipo fundamentalista. A dogmatização doutrinal não indica somente um ritual ligado ao culto religioso como tal, pois há um exercício político que se converte em prática e mecanismo de persuasão não apenas religiosa, mas também de cunho político e econômico. O exercício sistemático e ostensivo sufoca qualquer possibilidade de reação e crítica, pois se trata de um conteúdo que, presumivelmente, deseja não sucumbir a qualquer objeção e/ou dissidência.

Por isso, os tempos de pandemia, as exigências de um con-viver hospitaleiro não comportam qualquer discurso de tipo dianético, ortodoxo, estrafalário ou excêntrico. Os motivos são mais que evidentes. Seus efeitos também são irrefutáveis, principalmente quando se observa a proliferação e a rentabilidade triunfalista de lideranças ligadas a “igrejas” evangélicas. Evidentemente, nem todas elas comungam de um discurso fundamentalista. No entanto, quando se trata da ingerência na política, a ortodoxia de algumas igrejas neopentecostais consegue 
sobrepor-se com expressivo intrometimento. Além delas, o positivismo brasileiro, de certo modo, assumiu também a áurea de religião, influenciando diversas entidades do país. 4

Não há dúvidas que a opção por uma perspectiva desalinhada com os princípios da con-vivência repetiria os mesmos equívocos de gerações estupidamente egoístas e inconvenientes. Por isso, os dias atuais representam ser uma excelente oportunidade para um "novo" re-ligar e, deste modo, reafirmar os aspectos mais sagrados da vida: a hospitalidade convivial, de modo que a interação entre humanos, não humanos e a natureza "como um todo" seja o eixo de intersecções mancomunadas.

\section{Tempos para re-ligar e de enamoramento}

Esse último item tem como objetivo refutar qualquer referência de tipo ortodoxo e radical, isto é, de qualquer teísmo, seja ele cienciológico, cristológico, quiromante, etéreo ou mercadológico proeminentemente fundamentalista. Nesse sentido, a expressão del senno di poi son piene le fosse ("as fossas estão cheias de profetas do passado”) manifesta não só o anacronismo das pretensões fundamentalistas, pois salienta o caráter maligno que, na sua versão estrafalária, repudia todo e qualquer desígnio para repensar a con-vivência saudável. No seu viés necrófilo, as pretensões da ortodoxia fundamentalista fortalecem a base para o individualismo e o verticalismo dinástico, renegando, portanto, qualquer preocupação com a con-vivência, a democracia, a divisão de poderem etc. e, em decorrência, àquelas políticas voltadas a diminuir a pobreza, a desigualdade entre as pessoas, a injustiça etc.

Frente a isso, as filosofias de vida - no sentido de con-viver e da convivência (Mitleben) - reforçam a necessidade de repensar as atuais características dessa civilização estúpida, idiota e com ressentimentos presunçosos. Esse carácter impregnado de vaidades encontra diferentes expressões. Para alguns, nosso tempo

\footnotetext{
${ }^{4}$ Esse é um tema a ser aprofundado, pois os ideais do Positivismo ainda persistem inclusive no campo acadêmico, sem falar das "igrejas" positivistas brasileiras.
} 
reflete um individualismo possessivo (Macpherson, 1979), também retraduzido por parochial monologüism (Pizzi, 2018), individualismo idiota (García-Marzá, 2018), egoísmo racional (Habermas, 2015), entre outras designações. Para outros, trata-se de um modelo desmesurado, "em nome de uma fantasia de onipotência que é, ao mesmo tempo, ultraliberal e tecnófila" (AMOR PAN, 1918, p. 277). Tal individualismo poderia também ser afiançado de neopentecostal-necrófilo. Na verdade, os impulsos do modelo hiperindividualista criaram uma obcecação do indivíduo "por si mesmo”, transformando-se em "paixão de massas” (AMOR PAN, 1918, p. 277).

Então, para não cair no ostracismo de uma idolatria estrafalária - e, portanto, uma miragem quimérica -, o texto apresenta como eixo de convecção o con-viver. Para tanto, é fundamental re-ligar, uma noção também vinculada às religiões. Entretanto, não se trata de uma nova religiosidade, até mesmo porque o antepositivo latino religi abre um leque de acepções. O vínculo com a religião, no seu sentido deísta, é apenas um dos aspectos da lexicografia, pois religi também pode indicar algo ímpio, sacrílego ou proibido pela religião. Nessa última versão, trata-se de uma retórica que separa e afasta os fiéis dos não adeptos, inviabilizando a con-vivência. Ao ser assim, religi concerne a algo que não pode ser aplicado a todas as situações vivenciais, ou seja, uma exigência que não pode ser universalizada.

Diante disso, o primeiro ponto se reporta ao significado de ligar que, do idioma espanhol, é literalmente traduzido por paquerar. De origem latina, ligare é sinônimo de unir, estabelecer contato ou criar vínculos com outra ou outras pessoas - e, inclusive, com as "coisas" -, demonstrando um interesse com efeitos vivazes. Nesse sentido, a noção de sujeito coautor advém do reconhecimento dos demais. Por isso, “o reconhecimento recíproco constitui-se em um vínculo, uma ligatio que está presente como presença viva” (CORTINA, 2017, p. 100). Desde modo, a ligatio torna obrigatório o compromisso mútuo a respeito dos vínculos de um con-viver saudável; jamais de rechaço ou discriminação. 
O ensejo e a ação de seduzir alguém não significa instrumentalização, pois requer a anuência das partes, na medida em que se trata de uma relação intersubjetiva. A confiança recíproca passa a ser, então, um fator fundamental para esse tipo de sedução, paqueração ou enamoramento. Deste modo, a insinuação não significa apenas a necessidade de chamar a atenção ou em demonstrar interesse para ganhar a simpatia ou seduzir, pois está relacionada à criação de vínculos mútuos entre os coautores.

Como já foi destacado, Fromm insiste na arte de "amar e cooperar" em detrimento aos impulsos "de destruir, dominar, reprimir, sufocar a vida." Para ele, o segundo aspecto está relacionado ao "enamoramento" pela morte. Todavia, no sentido de amar e cooperar, o enamorar-se pode transformar-se, então, em ponto de partida para o re-ligar. Por isso, se a modernidade e o colapso atual da sociedade podem estar associados a um modelo patológico e a um vazio de sentido, a proposta de re-ligar reafirma a exigência de promover os laços e os apelos concernentes ao con-viver. Em outras palavras, trata-se de um reencanto pela morada terrenal e ao entorno vivencial e, ainda, em assegurar as necessidades vitais do ser humano e da natureza.

Deste modo, o sintagma con-viver se converte em eixo de interconexão de um enamoramento pela vida e pelo con-viver. Essa parece ser a tendência de qualquer filosofia social crítica. A negação da capacidade de reconhecer alteridades revela uma anomalia patológica. O fundamentalismo exige uma adesão cega do indivíduo com essa ou aquela "igreja" - e, consequentemente, com o "pastor" fulano de tal. E quem está fora disso, sofre, então, o assédio ou a intimidação de não possuir nenhum vínculo.

A reversão da tendência patológica, típica de um ressentimento doentio e anômico, possibilita transformar a vitalidade em sedução para o con-viver na pluralidade, seja entre humanos, não humanos e com a natureza. Como adverte Habermas, não se pode brincar com "charlatanismos" (2015, p. 11). Por isso, não é o momento para persistir com a ortodoxia ultraconservadora de um liberalismo 
dinástico - e, portanto, individualista e idiota -, incapaz de garantir a convivência hospitaleira. A situação atual exige reinvenções, sem o que não haverá garantias de que, num futuro próximo, a humanidade perecerá ante a eminência de patologias sociais ainda mais desgraciosas que a atual pandemia.

Para Fromm, as duas orientações vivenciais contrastam “o amor à vida” em contraposição à sede de sangue. De acordo com Honneth, as relações pessoais envolvem "o ser amado, o amigo ou a esposa”. Esses vínculos pessoais estão ligados também à amizade, ao "apreço e afeto, de modo que a conexão seja vivida" e esteja estruturada "mediante a confirmação mútua" (2014, p. 175). Em outras palavras, a autorrealização pessoal está diretamente ligada a um "nós” social e intersubjetivo do qual todos fazemos parte. Esse mútuo compromisso exige vínculos que ligam e re-ligam, sem cessar, o enamoramento pelo con-viver.

A proposta de uma con-vivência saudável e hospitaleira não pode desprezar a vitalidade das comunidades religiosas. Nesse sentido, a "renovação ritual da solidariedade social” é, sem dúvidas, um elemento significativo inerente às comunidades religiosas (HABERMAS, 2015, p. 84-5). No caso, o pensamento religioso-metafísico conserva sua vitalidade e oferece inspirações para os cidadãos não crentes, evitando qualquer distopia patológica. Assim, o con-viver entre distintas "comunidades", na pluralidade, evita cair no fundamentalismo de sistemas autopoiéticos, que simplesmente buscam impor sua própria lógica a qualquer "cidadão do mundo".

$\mathrm{Na}$ verdade, o con-viver se apoia em uma filosofia centrada na vida, de forma a configurar as linhas mestras de uma hospitalidade livre de perversões patológicas e patologizantes. A noção de "vivência plena” (Voll-erleben) - ou na plenitude - possibilitaria, então, "superar qualquer ponto de vista particular" (SCHWAB, 2018, p. 245). Esse desafio não se limita aos humanos em si, pois também se relaciona "com a percepção da natureza" (SCHAWB, 2018, p. 246). Ou seja, o re-ligar e o enamoramento pela con-vivência implicam na superação das patologias sociais sem, com isso, manter os humanos apartados e dissociados do 
contexto ecológico (no seu sentido lato). No caso, todos os seres da natureza poderiam ser os verdadeiros atores e artistas dessa comunidade de interação.

Nesse ponto, Fromm pode ser classificado como um pensador com fortes vínculos com a corrente "filosofia da vida". Na esteira desse movimento mundovital, Hans-Rüdiger Schwab menciona autores como: Willhelm Dilthey, Georg Simmel, Lou Andreas-Salomé, Edmundo Husserl, Martin Buber, Albert Schweitzer, Henry Bergson, Jürgen Habermas, entre outros.

Como é possível perceber, a "filosofia da vida" está presente no pensamento alemão do final do século XIX e persevera no século XX, alcançando os dias de hoje. A seu modo, cada pensador foi desenhando uma forma própria ligada à biofilia, com o fim de aguçar a "percepção de e o cuidado e a atenção diante de para realçar o mundo comum (Mitwelt) a todos e, ainda, estimular a con-vivência (Mitleben) e a compaixão (Mitfühlen).” Então, o foco na realidade, ou seja, no entorno vivencial permite olhar de outro modo aos "nós", isto é, aos sujeitos coautores, assegurando-lhes o "papel central" de protagonistas na "consecução da con-vivência" (SCHWAB, 2018, p. 257).

Em seu texto, Schwab destaca a trajetória do pensamento Lou AndreasSalomé, pensadora do final do século XIX, salientando os aspectos semânticos introduzidos por Wilhelm Dilthey, para quem, a "filosofia da vida, deve uma essência acadêmica" (SCHWAB, 2018, p. 245). Em um contexto "racionalmente desencantado e desintegrado em elementos isolados e coisificados", o resgate de sentido da vida ocorre através de uma reflexão que possa sintonizar com a vivência (Erleben) e a con-vivência (Mitleben). Nos anos 20 do século XX, Husserl utiliza esta semântica, embora em outro contexto, introduzindo a expressão "vida consciente" para mostrar que o "sujeito se experimenta como um estar aí com os outros (daseiend mit anderen), cujo presente não se expressa na vigência do Ego individual" (SCHWAB, 2018, p. 251). O "estar" com os outros é, sem dúvidas, a dádiva de poder con-viver, ou seja, uma experiência de vida compartilhada mutuamente; enfim, a capacidade de "viver com e para os outros" (APARISI, 2018, p. 408). 
Schwab não menciona Erich Fromm como alguém ligado a este movimento filosófico. Todavia, a categórica insistência na biofilia, em contraposição à necrofilia, transforma Fromm em um dos inspiradores dessa filosofia ligada à vida e ao con-viver. Em Fromm, a insistência na contraposição entre os impulsos de “amar e cooperar" frente à inospitalidade necrófila - "de destruir, dominar, reprimir, sufocar a vida” - evidencia sua vinculação ou a propensão irresistível de um pensar preocupado com a vida. Para ele, essa vitalidade criadora é inerente à noção de biofilia. Por isso, a análise da religião no escopo da ortodoxia neopentecostal permite identificar também as incongruências de qualquer fundamentalismo e, desse modo, desbaratar um delineamento devastador, beligerante e necrófilo.

Sem dúvidas, o con-viver desloca a centralidade do antropocentrismo avassalador - típico da atual civilização das estupideces -, e realoca o eixo na convivência saudável. Nesse movimento, a hospitalidade não se relacionada simplesmente ao trato amável e afável aos humanos, porque exige também a convivência saudável em um habitat que congregue todos os seres e o próprio planeta. Neste sentido, diversos conceitos vigentes - alguns deles considerados e reconhecidos como determinantes até pouco tempo - deverão, simplesmente, desaparecer. Com as transformações, é bem provável que os professores e pesquisadores, assistentes sociais e enfermeiros, cuidadores e ambientalistas, por exemplo, tenham muito mais importância que os banqueiros especuladores e dos gestores dos fundos de operações financeiras.

\section{Considerações finais}

A conclusão não muda o tom do texto. Na verdade, nosso tempo é de colapso, e não de crise. A crise pode ser momentânea e passageira. Mas a pandemia - uma das palavras mais pronunciadas ultimamente - mostra seu rosto mais estapafúrdio da globalização "sem sujeitos" (PIZZI, 2018). Essa face pandêmica 
carrega um enlace pandemônico, ou seja, revela um estado extremo, arrefecendo ou destruindo o enamoramento pela vida. Por isso, os dias atuais se ressentem da capacidade de responder aos desafios de um "individualismo estúpido" e idiota. Às vezes, os apelos estapafúrdios de milagreiros inescrupulosos e sem ressentimento e, ainda, movidos pelo afã monetarista, entorpece esse re-ligamento com o conviver, subtraindo qualquer tipo de hospitalidade ligada a uma con-vivência saudável.

A alternativa da convivência hospitaleira se alinha à necessidade do reencanto pelo con-viver, isto é, o re-enamoramento pela vida em todas as suas dimensões. Para evitar cair no vazio de sentido, é preciso reinventar e, assim, reafirmar o impulso por estilos de vida capazes de garantir uma morada saudável a todos. Por isso, é preciso insistir com os sujeitos realmente dispostos a assumir o ônus de um projeto de sociedade capaz de restabelecer os vínculos fundamentais com a filosofia da vida. Não se trata apenas de frear a derrocada e a ruína, fruto da ineficiência de um capitalismo "sem sujeitos", mas de empreender outros mundos necessários.

Por fim, o colapso da atual civilização das estupidezes exige mudanças radicais nas atuais formas de convivência intersubjetiva. Essas exigências deverão forçar transformações significativas não apenas em relação aos significados e usos de conceitos vigentes - alguns deles muito diletos até os dias de hoje -, mas na capacidade de reestruturar os vínculos de uma hospitalidade garantidora da convivência saudável. Sem essa mudança, não será possível evitar a degradação inerente a um estilo de vida comprovadamente insustentável, porque ele é, simplesmente, belicoso e macabro. 


\section{REFERÊNCIAS}

AMOR PAN, J. R. Mejora humana, posthumanismo, liberalismo y capitalismo: ¿Los cuatro jinetes del apocalipsis? in: GARCÍA-MARZÁ, D. et al. Homenaje a Adela Cortina: ética y filosofía política. Madrid: Tecnos, 2018. p. 273-283.

APARISI, J. C. S. El humor ético: capacidad para el desarrollo humano y virtud cordial. In: GARCÍA-MARZÁ, D. et al. Homenaje a Adela Cortina: ética y filosofía política. Madrid: Tecnos, 2018. p. 407-419.

CORTINA, A. ¿Para qué sirve realmente la ética? Barcelona: Paidós, 2013.

CORTINA, A. Aporofobia, el rechazo al pobre. Barcelona: Paidós, 2017.

FROMM, E. La patología de la normalidad. Barcelona: Paidós, 1994.

GARCÍA-MARZÁ, D. et al. Introducción. In: GARCÍA-MARZÁ, D. et al. Homenaje a Adela Cortina: ética y filosofía política. Madrid: Tecnos, 2018. p. 11-14.

HABERMAS, J. Mundo de la vida, política y religión. Madrid: Trotta, 2015.

LEFORT, C. Democracy and political theory. Cambridge: Polity Press, 1988.

MACPHERSON, Crawford B. A teoria política do individualismo possessivo de Hobbes até Locke. Rio de Janeiro: Paz e Terra, 1979.

MICHELINI, D. J. Argumentos y creencia. ¿Es posible traducir los contenidos de fe al lenguaje secular? In: GARCÍA-MARZÁ, D. et al. Homenaje a Adela Cortina: ética y filosofía política. Madrid: Tecnos, 2018. p. 165-176.

PIZZI, J. Democracias bajo efectos clikcbait. La gramática pronominal como respuesta a la virtualidad tecnocrática. Veritas: revista de filosofía y teología, Santiago de Chile, n. 39, p. 33-53, abr. de 2018.

PIZZI, J. Parochial monologuism unde the guise of "universal dialogue" (ISUD). Topologik: international journal of philosophy, educational and social sicences, n. 21, p. 30-45, first semester 2017.

SCHWAB, Hans-Rüdiger. La conectividad del todo. Lou Andreas-Salomé y las implicaciones éticas del concepto Mitleben en el pensamiento moderno. GARCÍA-MARZÁ, D. et al. Homenaje a Adela Cortina: ética y filosofía política. Madrid: Tecnos, 2018. p. 243-257.

YTURBE, C. Laicidad. In: PEREDA, C. (ed.). Diccionario de justicia. México: Siglo XXI Editores, 2016. p. 299-303. 